Review Article

\title{
Toward Understanding the Role of Aryl Hydrocarbon Receptor in the Immune System: Current Progress and Future Trends
}

\author{
Hamza Hanieh \\ Biological Sciences Department, King Faisal University, P.O. Box 380, Hofouf 31982, Saudi Arabia \\ Correspondence should be addressed to Hamza Hanieh; hhanieh@kfu.edu.sa
}

Received 26 July 2013; Accepted 14 October 2013; Published 6 January 2014

Academic Editor: Silvia Gregori

Copyright ( 2014 Hamza Hanieh. This is an open access article distributed under the Creative Commons Attribution License, which permits unrestricted use, distribution, and reproduction in any medium, provided the original work is properly cited.

\begin{abstract}
The immune system is regulated by distinct signaling pathways that control the development and function of the immune cells. Accumulating evidence suggest that ligation of aryl hydrocarbon receptor (Ahr), an environmentally responsive transcription factor, results in multiple cross talks that are capable of modulating these pathways and their downstream responsive genes. Most of the immune cells respond to such modulation, and many inflammatory response-related genes contain multiple xenobioticresponsive elements (XREs) boxes upstream. Active research efforts have investigated the physiological role of Ahr in inflammation and autoimmunity using different animal models. Recently formed paradigm has shown that activation of Ahr by 2,3,7,8tetrachlorodibenzo-p-dioxin (TCDD) or 3,3' -diindolylmethane (DIM) prompts the differentiation of CD $4^{+}$Foxp $3^{+}$regulatory T cells (Tregs) and inhibits T helper (Th)-17 suggesting that Ahr is an innovative therapeutic strategy for autoimmune inflammation. These promising findings generate a basis for future clinical practices in humans. This review addresses the current knowledge on the role of Ahr in different immune cell compartments, with a particular focus on inflammation and autoimmunity.
\end{abstract}

\section{Introduction}

The aryl hydrocarbon receptor (Ahr) is a transcription factor belonging to the basic helix-loop-helix-Per-Arnt-Sim (bHLH-PAS) superfamily of proteins, which is ubiquitously expressed in vertebrate cells $[1,2]$. For many years, Ahr has been described to mediate the mechanisms that undertake the environmental toxicity and immunotoxicity [3]. Nevertheless, later progress has expanded Ahr functions much beyond to include aspects of the circadian rhythm, reproduction, redox potential, autoimmunity, and various cellular processes [4-10]. These multiple physiological functions of Ahr have been confirmed using different animal models including Ahr-null mice, hypomorphs, and more recently cell-specific conditional deletions of Ahr.

In immunological aspects, Ahr is abundant in most immune cells, if not all, albeit at different levels, reviewed in [11]. It mediates the proliferation, differentiation, and cytokines secretion of adaptive and innate immune cell compartments, in particular T helper (Th)-17, regulatory $\mathrm{T}$ cells (Tregs), and dendritic cells (DCs) that play profound roles in autoimmunity [12]. Furthermore, many inflammatory response-related genes have potential xenobiotic-responsive elements (XREs) embedded in upstream sequences. It is likely that these polymorphisms can be transcriptionally regulated by Ahr, and, therefore, modulate various autoimmune diseases.

Accumulating evidence has clearly linked Ahr to several murine autoimmune models including experimental autoimmune encephalomyelitis (EAE) $[13,14]$, ulcerative colitis (UC) [15, 16], collagen-induced arthritis (CIA) [7], and Sjögren's syndrome [17]. However, the underlying mechanisms are largely anonymous. This review provides current state of the art on the role of Ahr in the differentiation and functions of different immune cell compartments, focusing in particular on inflammation and autoimmunity. In addition, the paper discusses the proposed mechanistic details that undertake the actions of Ahr.

\section{Ahr: Background and Biochemistry}

The Ahr is a heterodimeric ligand-dependent protein activated by a structurally diverse variety of ligands, which fit 
minimum requirements of aromaticity and hydrophobicity (Figure 1). The endogenous Ahr ligands are a long-listed group of chemicals synthesized in the organism, including indigoids, equilenin, and metabolites of arachidonic acid, heme, and tryptophan, which are highlighted in recent reviews $[2,11,18,19]$. The Ahr is activated vigorously by the tryptophan photoproducts 6-formylindolo-[3,2-b]-carbazole (FICZ) and 6,12-diformylindolo-[3,2-b]-carbazole (dFICZ) that are induced by UV in the skin. More recently, kynurenine (Kyn), the tryptophan metabolite induced by indoleamine 2,3-dioxygenase (IDO), is considered as an Ahr agonist [20]. Further tryptophan metabolite, the $2-\left(1^{\prime} \mathrm{H}\right.$-indole- $3^{\prime}$ carbonyl)-thiazole-4-carboxylic acid methyl ester (ITE), is reported to exert Ahr activation in lungs fibroblasts [21] and myofibroblast [22]. The essential role of tryptophan in Ahr activation suggests that more derived tryptophan metabolites may be able to activate Ahr and arelikely to be characterized in the future. Furthermore, the naturally occurring Ahr ligands are predominantly found in plants such as certain flavonoids and glucosinolates $[9,23,24]$.

Since the discovery over 3 decades [25], Ahr has been intensively studied for its physiological significance using man-made ligands. The best-characterized exogenous ligands of Ahr, which attract the attention of many groups, are a wide variety of ubiquitous polycyclic aromatic hydrocarbons (PAHs), halogenated aromatic hydrocarbons (HAHs), and polychlorinated biphenyls (PCB) compounds, reviewed in [18]. The xenobiotic 2,3,7,8-tetrachlorodibenzo-p-dioxin (TCDD), as named by toxicologist, is the most potent Ahr ligand that binds with high affinity and stability. Its chlorine residues are considered advantageous for Ahr research since they prevent metabolic breakdown, which sustain prolonged Ahr signaling, and today TCDD is the Ahr agonist of choice. Conversely, the long half-life of TCDD is a hindrance, since the prolonged activation of Ahr deregulates responsive genes and the consequent outcomes. Additionally, exposure to TCDD exerts diversity of toxic and biological effects, including tumor promotion and immuno-, hepato-, cardio-, and dermal toxicity, reviewed in [26].

Residing in cytosol, Ahr complexes with the chaperons prostaglandin E synthase 3 (P23), heat shock protein (Hsp)90, and Ahr-interacting protein (AIP). This dimerization keeps Ahr inactive and prevents proteolysis. Activation allows Ahr to dissociate these chaperons and expose the $\mathrm{N}$ terminal, which facilitates the translocation of Ahr/ligand complex into the nucleus. In the classical pathway, Ahr dimerizes with another bHLH-PAS member the Ahr nuclear translocator (Arnt) or hypoxia-inducible factor (HIF)- $1 \beta$, reviewed in $[27,28]$. The Ahr/Arnt heterodimer binds to the small conserved promoter elements XREs, also termed dioxin-responsive elements (DREs), which recruits cofactors (p300, cAMP, CREB, and RIP140) to accelerate expression of the responsive genes [29]. The Ahr mediates toxicity via upregulation of gene expression of the xenobioticmetabolizing enzymes such as Cyp1A1, Cyp1A2, Cyp1B1, Gst1A1, Ugt1a6, and Aldh3al, reviewed in [1,30]. A second conserved Ahr promoter element, Ahr-II, has been identified, which recognizes Ahr with additional cofactor(s) only [31].
However, the paucity of studies has investigated the physiological consequences of Ahr binding to the Ahr-II.

The signaling pathway of Ahr is conserved and can work independently or in interaction with other pathways. Proof that Ahr cross talks with different pathways is already established, which seemingly adds more complexity to the mechanism of Ahr action. For instance, we and others have shown that Ahr interacts with signal transducers and activators of transcription (STAT) 1 [32], nuclear factor (NF)- $\kappa$ B subunits [33], transacting transcription factor (Sp1) [34], estrogen receptor (ER), and kinases such as src [35]. Hundreds of genes incorporated in a wide range of physiological responses have the core-pentanucleotide sequence $\left(5^{\prime}\right.$-TNGCGTG- $\left.3^{\prime}\right)$ of the XREs [29]. Therefore, it is to be suggested that the alternative pathways specify the Ahr responsive genes and create downstream differences in a condition-specific fashion.

\section{Ahr in Adaptive Immune Cells}

An adaptive immune response is triggered via activation, differentiation, and clonal expansion of the lymphoid lineage cells, $\mathrm{T}$ and $\mathrm{B}$ lymphocytes. This response is an overall outcome of a multitude of environmental and genetic factors. Since a long time ago, many immunotoxicological studies have clearly demonstrated that Ahr impairs immune responses to a variety of pathogens such as the influenza virus [36], herpesviruses [17], and Streptococcus pneumoniae [37]. The Ahr exerts its immunosuppression via drastic changes in thymic involution, thymocyte and T cell apoptosis, shifts in immune cell subsets, and splenic atrophy, reviewed in $[26,38]$.

Depending on the signal received, the $\mathrm{T}$ cells proceed to differentiate along transcription factor-specific pathways that give distinct $\mathrm{T}$ cell subsets. These lineage-specific transcription factors include T-bet for Th1, GATA3 for Th2, ROR $\gamma \mathrm{t}$ for Th17, and Foxp3 for Tregs. Interestingly, applying the promoter sequence analysis software, that is, TF search, shows that these transcription factors have potential XREs boxes in upstream sequences, albeit at different frequencies, assuming that activation of Ahr may directly/indirectly modulate the commitment of these $\mathrm{T}$ cell subsets. Nevertheless, the functional importance of these XREs in lineage commitment remains unclear.

3.1. Th1 and Th2. The expression of Ahr is not detected in mice Th1 and Th2 cells during differentiation [39]. However, application of Ahr agonists shifts the Th1/Th2 balance towards Th1 dominance by GATA3 inhibition, which ameliorates allergy [39] and allergic asthma [40] in mice models. Taken together, it may be expected that Ahr is implicated in modulation rather than in initiation of the normal differentiation of Th1/Th2 cells. The upstream sequence of Gata3 contains a high frequency of potential XREs boxes, while Ahr activation suppresses the Th2 differentiation. Therefore, more investigation should provide important mechanistic explanations. 
<smiles>Clc1cc2c(cc1Cl)Oc1cc(Cl)c(Cl)cc1O2</smiles>

2,3,7,8-Tetrachlorodibenzo-p-dioxin

(TCDD)

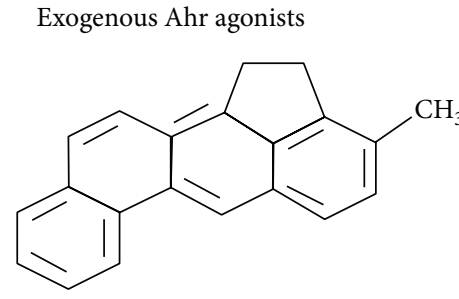

3-Methylcholanthrene

(3MC)

Endogenous Ahr agonists<smiles>C#CC1=C2C(=O)Nc3ccccc3C2C1=O</smiles>

Indirubin<smiles>O=c1cc(-c2ccccc2)oc2ccc3ccccc3c12</smiles>

$\beta$-Naphthoflavone

(BNF)

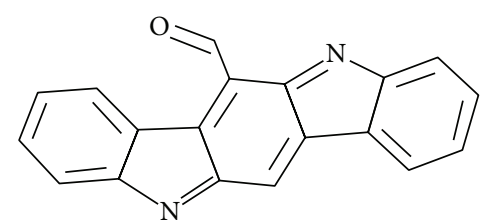

6-Formylindolo[3,2-b]carbazole

(FICZ)<smiles>C=[W]1C=C(CC2=NCc3ccccc32)c2ccccc21</smiles>

3, $3^{\prime}$-Diindolymethane (DIM)<smiles>Oc1ccc(C=Cc2cc(O)cc(O)c2)cc1</smiles>

3, 5,4' -Trihydroxystilbene

(Resveratrol)<smiles>O=C1CC(c2ccc(O)cc2)Oc2cc(O)cc(O)c21</smiles>

Naringenin<smiles>C=C1C=C(C(=O)c2nc(C(=O)OC)cs2)c2ccccc21</smiles>

2-(1'H-Indolo- $3^{\prime}$-carbonyl)-thiazole -4-carboxylic acid methyl ester (ITE)

Dietary Ahr agonists

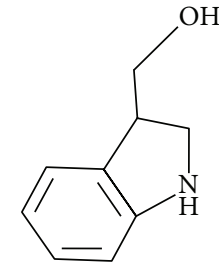

Indole-3-carbinol (I3C)

Ahr antagonists<smiles>Cc1ccccc1/N=N/c1ccc(Nc2ccnn2C)c(C)c1</smiles>

1-Methyl-N-[2-methyl-4-[2-(2-methyl phenyl) diazenyl]phenyl-1H-pyrazole-5-carboxamide (CH223191)<smiles>CC(C)n1cnc2c(NCCc3ccc(O)cc3)nc(-c3csc4ccccc34)nc21</smiles>

(SR1)

FIGURE 1: 2-dimensional structure of selected Ahr agonists and antagonists. 
Regulatory T cells (Tregs) are specialized population of T cells that are engaged in sustaining immunological self-tolerance and homeostasis. Deregulation of Tregs leads to severe autoimmune diseases, inflammatory bowel disease, and allergy. The interleukin (IL)6 in combination with transforming growth factor (TGF)- $\beta$ drives differentiation of Th17 cells by the specific transcription factor ROR $\gamma$ t. These cells do not produce IL- 4 or interferon (IFN) $-\gamma$. In fact, IL- 4 or IFN- $\gamma$ inhibits differentiation of Th17 cells. Interestingly, TGF- $\beta$ alone induces differentiation of Tregs by their lineage-specific transcription factor Foxp3, while IL-6 alone has inhibitory effect on Tregs and is incapable of directing differentiation of Th17 cells. Hence, differentiation and function of Tregs and Th17 subsets are reciprocally controlled, and their balance is critical for immune homeostasis and protection against inflammatory diseases. These subsets of CD4 lineage function through their secreted cytokines, while Th17 cells are defined by production of the proinflammatory cytokines IL17 and IL-22 that mediate exacerbation of inflammation and autoimmunity, and Tregs produce TGF- $\beta$ and IL-10 that oppose function of Th17 cells. The Tregs may also suppress the inflammatory response by CTLA- 4 that inhibits B7 on the antigen-presenting cells (APCs) and by secretion of granzymes and perforins that kill different effector $\mathrm{T}$ cells. Therefore, in several autoimmune disorders, that is, experimental autoimmune encephalomyelitis (EAE), experimental autoimmune uveoretinitis (EAU), and ulcerative colitis (UC), the decreased frequency of Tregs and the increased frequency of Th17 cells are associated with disease severity.

Box 1: T helper 17 and regulatory $\mathrm{T}$ cells.

Treating mice with TCDD ameliorates allergic sensitization by the inhibition of interleukin (IL)-4 [41]. Cytokines analysis during allergic sensitization with DNP-Ascaris extracts shows higher IL-5 production and IgE titre in Ahrnull mutant (B6Ahr $\left.{ }^{\mathrm{D} 1 / \mathrm{D} 1 \mathrm{~F}}\right)$ mice [39]. Relevant results using an allergic lung inflammation model show higher IL-5 production in $\mathrm{Ahr}^{-/-}$mice [42]. The stimulation of splenocytes from $A h r^{\mathrm{D} 1 / \mathrm{D} 1 \mathrm{G}}$ mice augments interferon (IFN)- $\gamma$ and IL12 production [43]. On the other hand, TCDD treatment suppresses the Th1 effector function by reducing IFN- $\gamma$ production $[13,14]$. This suppression may be attributed to the enhanced IL-10 that interrupts JAK-STAT pathway. In agreement, the inhibition of Ahr by resveratrol increases Th1 and Th2 cells [39], which is supported by our findings in the CIA model using $\mathrm{Ahr}^{-/-}$mice [7].

3.2. Th17 and Tregs. The Ahr plays pivotal roles in the differentiation and functions of the $\mathrm{CD} 4^{+}$effector cells Th17 and Tregs, the hallmark of autoimmunity (see Box 1). Data from several groups reveal that Ahr-deficient mice have a defective differentiation of these $\mathrm{T}$ cell subsets and that Ahr is highly expressed in both human [44] and mice Th17 $[13,32,44]$ cells. Consistently, activation of Ahr by certain agonists enhances Th17 expansion in both species [32, 44]. Mechanistic investigations unravel that the interaction of Ahr with STAT5 down-regulates STAT5 phosphorylation and hence reduces IL-2 production, resulting in an induction of Th17 cells $[32,45]$.

Also, it is suggested that, under Th17-polarizing conditions, STAT3 and Ahr upregulate the expression of Aiolos [46]. Using Aiolos-deficient mice, the authors demonstrate that Aiolos silences the Il2 locus, promoting the Th17 differentiation in vitro and in vivo. More recently, our data show that activation of Ahr by FICZ enhances the Th17 differentiation via upregulating microRNA (miR)-212 that targets B-cell lymphoma (Bcl)-6, a negative regulator of Th17, and that miR-132/212-deficient mice have an impaired differentiation of this $\mathrm{T}$ cell subset [47].

The IL-17- and IL-22-producing Th17 cells contribute to the host defense against extracellular pathogens, and they are implicated in the pathogenesis of autoimmune disorders. The interaction between Ahr and IL-22 was first reported when Veldohoen and colleagues [44] demonstrated that Th17 from $\mathrm{Ahr}^{-/-}$mice did not produce IL-22 and that FICZ treatment in the wild type increased the production of IL-17 and IL22 in these cells, which worsened EAE. In related studies in human memory T cells, it was shown that FICZ or TCDD increased the IL-22 production but not that of IL-17 [48, 49]. In contrast to the observations in mice, when the effects of FICZ on the differentiation of IL-17- and IL-22-producing cells were studied, the data showed that FICZ promoted IL22-producing cells but inhibited the generation of Th17 [48].

Under Th17-polarizing conditions, Ahr interacts with JAK-STAT pathway to exert its modulatory effects on the production of IL-17 and IL-22 by Th17 cells [32]. Consistently, retroviral transductions of $A h r$ alone or combined with RORc2 under different skewing conditions, except for Th17 cells, are insufficient to induce the production of IL-17 and IL-22 $[38,44]$. Interesting data indicate that nitric oxide (NO) suppresses the differentiation and functions of polarized human and murine Th17 cells, and deletion of inducible NO synthase (iNOS) in mice $\left(\mathrm{Nos}^{-/-}\right)$results in more severe EAE manifested by an increased production of IL-17A [50]. The authors suggest that NO also inhibits the expression of Ahr in Th17 cells concomitant with the inhibition of IL-22, IL-23r, and CYP1A1. In this regard, liver $\mathrm{x}$ receptor (LXR) suppresses the differentiation of Th17 cells and the expression of IL-17 [51, 52]. Mechanistically, LXR-induced Srebp-1 inhibits the IL-17 transcription through a cross talk with Ahr that inhibits binding of Ahr to the Ill7 promoter [52]. 
It is now clearly evident that activation of Ahr enhances the differentiation of Tregs. For instance, activation of Ahr by TCDD induces $\mathrm{CD} 4^{+} \mathrm{Foxp}^{+}$Tregs in vitro and in vivo $[13,14$, 32]. The role of Ahr in promoting the differentiation of Tregs is further confirmed using Kyn [53] and VAF347 [54]. Recent studies suggest that the naturally occurring Ahr ligands such as diindolylmethane (DIM) [55] and naringenin [9] stimulate the induction of $\mathrm{CD}^{+}{ }^{+} \mathrm{Foxp}^{+}$Tregs.

The Tregs from Ahr-deficient mice show lower levels of IL-10 [56, 57]. This may support that the Ahr-deficient mice have elevated levels of IL-12 and IFN- $\gamma$, the cytokines inhibited by IL-10 [58, 59]. Along the same line, Ahr physically interacts with c-maf to control the transcriptional activity of the Il10 promoter in Tregs [57]. Interestingly, Ahr/c-maf heterodimer likely plays a role in the differentiation of Th17 cells via regulating IL-22 expression [60]. These observations may support that Ahr is essential, but works differentially, in the differentiation and functions of Th17 and Tregs.

New Tregs that express Foxp3 and produce IL-10 have been identified in mice, so-called Trl. It is suggested that Ahr enhances the generation of these cells and mediates the production of IL-10 and IL-21 via interaction with c-maf, resulting in amelioration of EAE [56]. Relevant findings show that the probiotic Bifidobacterium breve induces IL-10producing Trl cells that express Ahr, c-maf, and IL-21 and that DCs treated with this probiotic are capable of inducing Trl cells in mice [40]. In humans, activation of Ahr in the presence of TGF- $\beta 1$ induces CD $4^{+}$Foxp $3^{+}$Tregs, which suppresses responder $\mathrm{T}$ cells through different mechanisms including the ectonucleoside triphosphate diphosphohydrolase CD39 [59]. The latter mechanism is also conceivable since CD39 deficiency is associated with an exacerbated autoimmune inflammation in human and murine models. For a recent review, see [61].

3.3. Th22. The Th 22 cells, with the CCR $6^{+} \mathrm{CCR} 4^{+} \mathrm{CCR} 10^{+}$ phenotype, are a distinct $\mathrm{T}$ cell subset with specific genes expression, in which Ahr is the key transcription factor. These cells produce IL-22, but not IL-17, which is upregulated in patients with autoimmune diseases including systemic lupus erythematosus (SLE) [63], multiple sclerosis (MS) [64], rheumatoid arthritis (RA) [65], and Sjögren's syndrome [66]. Therefore, Th22 cells may be an additional player in the scenario of autoimmunity.

Direct exposure to TCDD favors the emergence of IL-22secreting $\mathrm{CD}^{+}{ }^{+}$cells in humans [49]. Consistently, VAF347 promotes the differentiation of naïve $\mathrm{CD}^{+}$into IL-22secreting cells [67]. The data from the same study suggest that VAF347 prompts the differentiation of human monocytes into DCs capable of directing the differentiation of naive $\mathrm{CD} 4{ }^{+}$cells to secrete IL-22 but concomitantly inhibits IL-17. Therefore, Ahr selectively enhances IL-22 in Th22 cells. However, it remains unclear what the mechanistic explanation of this selectivity might be, though the promoter regions of Ill7 and Il22 contain XREs boxes, and whether this selectivity could be of therapeutic benefits.
3.4. $\mathrm{CD} 8^{+} \mathrm{TCells}$. Although the role of $\mathrm{Ahr}$ in $\mathrm{CD} 4^{+}$cells has been intensively studied, more studies are required to address the physiological significance of $\mathrm{Ahr}$ in $\mathrm{CD}^{+}$cells (CTLs). Several groups have shown that TCDD suppresses the proliferation and differentiation of influenza virus-specific CTLs, reviewed in [58]. However, mechanistic studies are limited, which makes it difficult to interpret. Notably, the suppressive effect of TCDD on DCs during influenza infection is also reported [36], and the early $\mathrm{CD} 8^{+}$functions during viral infection are $\mathrm{CD}^{+}$independent. Therefore, it may be presumed that TCDD suppresses CTLs functions during viral infection indirectly by suppressing the DCs.

The modulatory effects of Ahr on the differentiation and functions of CTLs have been studied in allograft aspects. Activation of Ahr is associated with suppression of the allospecific CTLs responses through a mechanism that is Ahr dependent. However, for TCDD to suppress alloresponse, treatment must occur before activation of the CTLs [68], suggesting that Ahr may be necessary for the initial stages of CTLs activation.

Sharing some commonalities with $\mathrm{CD}^{+}$cells, TCDDactivated Ahr enhances CD25 expression on $\mathrm{CD}^{+}$cells, which induces a CTL phenotype termed $\mathrm{CD} 8^{+}$Tregs that are capable of suppressing responder $\mathrm{T}$ cells and proinflammatory cytokines [69]. Deregulation of these cells has been recently linked to certain animal models of autoimmunity such as EAE [70], UC [71], and CIA [72]. However, the significance of Ahr in these cells in relevance to autoimmunity is awaiting further investigation.

3.5. B Cells. Little is known about the role of Ahr in the differentiation of $B$ cells. It has been shown that Ahr deficiency in B cells is associated with more immature cells, while TCDD treatment reduces the mature cells [73]. Activation of Ahr impairs humoral immunity at many endpoints [74] and increases susceptibility to infections [36, 75]. For example, TCDD mediates the reactivation induction of EBV, a ubiquitous herpesvirus that infects $>90 \%$ of the world's population, by transactivating BZLF1, an Ahr responsive gene, which consequently can be a risk factor for Sjögren's syndrome [17].

The TCDD treatment in mice decreases the number of IgM-secreting plasma cells and delays the differentiation of $\mathrm{B}$ cells by inhibition of the activator protein (AP)- 1 and the activation of the transcription factor Bach2 [76]. In lines, TCDD suppresses IgE production in mice models while inhibiting IgM in transformed mice cell line, reviewed in [77]. The suppressive effects of TCDD on Ig expression in mice may be mediated, at least in part, by the repression of the $3^{\prime}$ Igh regulatory region $\left(3^{\prime} \operatorname{Igh} R R\right)$ [78]. Although the number of published reports studying human B cells is limited, the available data show that the sensitivity of human and mice B cells to suppression by TCDD is comparable; see [77]. In contrast to the data in mice, TCDD activates the $3^{\prime} I g h R R$, suggesting species differences in the mode of action of TCDD. Interestingly, hs1,2, the enhancer of $3^{\prime} I g h R R$, has XREs in the invariant sequence [78], and it has been correlated with many autoimmune diseases in humans [79-81], suggesting that 
TCDD may influence autoimmune inflammation through regulation of the hs1,2.

Activation of Ahr by ITE suppresses the differentiation of $B$ cells into Ig-secreting plasma cells and the production of $\operatorname{IgM}$, IgE, and IgG1 [82]. In an effort to provide mechanistic details, they found that the activation of Ahr suppresses the mRNA expression of secreted-type Ig and plasma cell-specific genes such as $\gamma 1 \mathrm{GLT}$ and $\varepsilon$ GLT that are necessary for class switching. However, some questions are still unanswered. For example, what are the active interplays of Ahr with other signaling pathways in B cells?

\section{Ahr in Innate Immune Cells}

Stimulation of the myeloid lineage cells including granulocytes, macrophages (MФ), DCs, and natural killer (NK) cells not only forms the innate immunity as a first line of defense, but also shapes the subsequent adaptive responses. A number of outstanding reviews have addressed the modulatory effect of Ahr in innate immune responses [11, 30, 83]. Herein, the review presents an overview of recent reports that investigated the potential role of Ahr in the differentiation and function of innate immune cells as well as the suggested mechanistic illustrations.

Fundamental genes that are relevant to the innate immune response have different frequencies of XREs in the promoter regions, including, all toll-like receptors (TLRs), complement genes, IL-6, TNF- $\alpha$, and IL-1r [62]. Furthermore, Ahr expression is detected in the cells of the innate immune system, such as DCs, MФ, and NK cells; see [11]. It is congruent, therefore, that activation of Ahr in these cells modulates different features of the innate immune response.

4.1. Neutrophils. Neutrophils are the most abundant leukocytes that mediate acute inflammatory response to numerous infections. Therefore, the role of Ahr in these cells has been studied synergistically in response to challenge. For example, TCDD treatment increases the recruitment of neutrophils in the lungs following influenza virus infection in mice, which worsens inflammation $[84,85]$. Interestingly, the genes of granulocyte-macrophage colony-stimulating factor (GM$\mathrm{CSF}$ ), granulocytes $(\mathrm{G})-\mathrm{CSF}$, and the neutrophil chemoattractant keratinocyte chemoattractant (KC) contain no XREs boxes, suggesting an indirect mode of action by TCDD that may include nonimmune cells. Supporting this notion, it is reported recently that elevated iNOS levels and neutrophil numbers in the influenza virus-infected lung result from Ahrdependent signaling in endothelial and respiratory epithelial cells, respectively [84].

In contrast, Veiga-Parga et al. [86] found that neutrophils and proinflammatory cytokines were less in the corneas of herpesvirus simplex-infected mice with TCDD treatment. In response to Streptococcus pneumoniae infection, neutrophils numbers were not increased in the TCDD-treated animals, and, notably, there was a trend of decreased number of phagocytes recovery in the lung lavage [37]. Furthermore, TCDD treatment before pleuritis initiation reduced the number of neutrophils during inflammation [87]. It is likely that the differences in TCDD administration time and/or dose contributed to the above-mentioned discrepancies.

4.2. DCs and MФ. Available data clearly indicate that DCs play prominent roles in autoimmune inflammation, which can be modulated by activation of Ahr. For example, TCDD promotes Tregs development indirectly by inducing IDO in DCs, which enhances Foxp3 expression [88]. Along the same line, ligation of Ahr by ITE induces tolerogenic dendritic cells (DCs) that are capable of enhancing the differentiation of Tregs [89]. However, the underlying mechanisms of these modulations remain to be defined.

To perform their function in bridging innate and adaptive immunities, immature DCs undergo substantial changes upon TLRs ligation, including the expression of costimulatory molecules and secretion of cytokines. It is quite evident from earlier and recent in vitro studies that Ahr ligation enhances DCs maturation and T cell stimulation capacity. These effects are characterized by the elevated expression of costimulatory molecules such as MHCII, CD40, CD54, CD80, CD86, and CD274 [90, 91].

The Fms-like tyrosine kinase 3 ligand (Flt3L) is used to induce the immature steady-state DCs that reside in peripheral immune tissues, whereas GM-CSF is used to generate the so-called inflammatory DCs. Exposure to TCDD, FICZ, or ITE reduces the number of bone marrow-derived steadystate DCs and the production of IL- 6, TNF- $\alpha$, IL-10, and IL-12, while these Ahr agonists do not exert such effects on mature DCs in mice [90]. In the same study, it is shown that TCDD decreases MHCII expression and upregulates CD80, CD86, and CD54, but FICZ and ITE selectively increase the percentage of MHCII, CD86, and CD54 on steady-state DCs. Treating the mice inflammatory bone marrow-derived DCs (BMDCs) with TCDD increases the gene expression of Ahr, TGF- $\beta$, and IDO $[88,92]$. In contrast, inactivated steady-state DCs upregulate gene expression of IDO only [90]. Collectively, it may be suggested that the modulatory effect of Ahr on DCs is population and ligand dependent.

Despite the commonalities they share, DCs and MФ create discrepancies at certain circumstances. For instance, while lipopolysaccharides (LPS) inhibit the production of IL-10 in MФ, BMDCs, and splenic DCs from $\mathrm{Ahr}^{-/-}$mice, the CpG inhibits the IL-10 in MФ [88, 93]. Furthermore, while Ahr expression is induced by LPS and CpG in both BMDCs and peritoneal MФ, Ahr deficiency enhances IL6 and TNF- $\alpha$ production in the latter only [93]. Mechanistically, the interaction of Ahr with STAT1 negatively regulates NF- $\kappa$ B activation in LPS-stimulated $M \Phi$, which may interpret, at least partly, the enhanced production of the proinflammatory cytokines in $\mathrm{Ahr}^{-1-}$ mice [93]. As an alternative pathway independent of STAT1, our data suggest that Ahr negatively regulates the production of IL-6 in MФ by the suppression of the histamine production [34]. The Ahr/Spl heterodimer abrogates Spl phosphorylation on Ser residues, which represses histidine decarboxylase expression.

In agreement with the anti-inflammatory role of Ahr, studies using the BMDM $\Phi$ and MCF-7 breast cancer cell line 
show that Ahr mediates the suppression of IL-6 [20, 94], IL$1 \beta$, and $\mathrm{Bcl}-2$ [94]. In a study conducted using BMDM $\Phi$ from LysM-Cre mice, it is suggested that Ahr negatively regulates IL- $1 \beta$ production through direct regulation of plasminogen activator inhibitor (Pai)-2 in a NF- $\kappa \mathrm{B}$-dependent mechanism [95].

4.3. NK Cells. The NK cells are another diverse population of lymphocytes with emerging functions not only in innate immunity but also in adaptive immunity. The Ahr is expressed in NK cells [96], and the modulatory effects of Ahr in these cells are reported, albeit conflicting results. Treating mice with TCDD exerts no effects on the number of NK cells recovered from the regenerating liver, but it reduces the number of intrahepatic NKT cells [97]. With regard to maturation and function, the authors indicate that TCDD transiently enhances CD69 expression on both NK and NKT cells, but it exerts no effect on the intracellular levels of IFN$\gamma$ in $\mathrm{NK}, \mathrm{NKT}$, or $\mathrm{CD}^{+} \mathrm{T}$ cells. In addition, it is found that TCDD augments activation of NKT cell and exacerbates immune-mediated liver injury induced by concanavalin A through a mechanism involving IFN- $\gamma$ and Fas ligand (FasL) [98].

In the absence of Ahr, NK cells show reduced cytolytic activity and capacity to control RMA-S tumor formation in vivo, despite having normal developmental and maturation markers [96]. Alternatively, the IDO and Kyn have suppressive effects on the proliferation of NK cells undergoing activation, but not resting cells [99]. Previous work demonstrates that Ahr is indispensable for IDO production [88]. Therefore, it may be postulated that upregulation of Ahr in NK cells has inhibitory effects on cell proliferation via upregulation of IDO.

Among the human $\mathrm{NK}$ cell intermediates, stage 3 $\mathrm{CD}_{4} 4^{-} \mathrm{CD} 117^{+} \mathrm{CD} 161^{+} \mathrm{CD} 94^{-}$cells, so-called immature $\mathrm{NK}$ cells, uniquely express Ahr and IL-22 [100]. These cells proliferate in direct response to DC-derived IL-15 and IL-1 $\beta$ in secondary lymphoid tissues. It is suggested that IL-1r1 $1^{\text {hi }}$ immature NK cells require exposure to IL- $1 \beta$ to sustain the expression of Ahr and IL-22 [100]. Importantly, it is shown in the same study that in the absence of IL- $1 \beta$ a greater portion of IL-1r 1 hi immature NK cells differentiate to stage 4 and acquire the cytotoxic potential and start to secrete IFN$\gamma$. Inhibition of Ahr by resveratrol increases the cytotoxic activity of the NK cells by involving activation of JNK and ERK signaling pathways [101]. Taken together, it may be suggested that the inhibitory effects of Ahr on the functions of NK cells may be attributed to arresting immature NK at stage 3. Hopefully, more studies will be conducted to determine the specific condition under which Ahr suppresses the functions of NK cells.

The invariant NKT (iNKT) cells are selected by CD1d and coexpress a restricted TCR repertoire [102]. Other phenotypic features of these iNKT cells include the expression of receptors such as CD161 and NKG2D [103, 104]. Although TCDD treatment does not affect the number of iNKT cells in Streptococcus pneumoniae-infected mice [37], recent results using FICZ suggest a modulatory effect of Ahr on cytokines production by human iNKT cells in vitro [105]. The iNKT cells have the capacity to produce IL-17. Interestingly, these IL-17-producing cells respond to Ahr activation and express Il23r and RORc genes [105], similar to conventional Th17 cells. Again, investigating the functions of Ahr in NK cells, in vivo and in vitro, is still in its infancy. Therefore, more studies may be required to investigate this resemblance between the roles of Ahr in iNKT and Th17 cells and their relevance to autoimmunity.

\section{Ahr in Barrier Organs}

Innate lymphoid cells (ILCs) expressing the nuclear receptor ROR $\gamma t$ are essential source of IL-22 and/or IL-17 that are associated with autoimmunity, reviewed in [106]. The ILCs play vital roles in the defense against intestinal pathogens, in homeostasis of the epithelia, and in the development of intestinal lymphoid follicles and, therefore, protect against inflammatory disorders. Quite recent comprehensive work shows that Ahr is expressed in ROR $\gamma \mathrm{t}^{+}$ILCs and that Ahr signaling is required for the expansion and maintenance of homeostasis of these cells in the gut [107]. The authors also show that mice fed on an indoles-deficient diet are highly susceptible to intestinal pathogen. In agreement, later results show that Ahr-deficient mice succumb to Citrobacter rodentium infection and that ROR $\gamma \mathrm{t}^{+}$ILCs from these mice have more apoptosis and less IL-22 production [75]. Therefore, it may be expected that ILCs mediate, at least in part, the modulatory properties of Ahr on autoimmune inflammation.

The receptor tyrosine kinase c-kit is expressed in $\mathrm{ROR} \gamma \mathrm{t}^{+}$ ILCs, and it is necessary for their cell development and differentiation [108]. Mechanistic investigation reveals that the upstream sequence of the c-kit gene contains functional XREs, which assigns the c-kit a downstream gene of Ahr signaling [23]. An independent study using NKp46 ${ }^{+}$ILCs suggests that the induction of Notch signaling undertakes the Ahr-mediated development of these cells [109]. It remains unclear whether these two mechanisms are results of differential roles of Ahr in these two ILCs subsets.

In addition to the above pointed function in $\mathrm{ROR} \gamma \mathrm{t}^{+}$ ILCs, the c-kit is required for expansion of the innate $\gamma \delta \mathrm{T}$ cells in the skin $[110,111]$. In Ahr-deficient mice, the $\gamma \delta \mathrm{T}$ cells in the skin [111, 112] and intestine [111] do not expand, which is likely attributed to the lower c-kit. Furthermore, it has been suggested that the activation of Ahr by dietary ligands is essential for stable functions of $\gamma \delta \mathrm{T}$ cells in the gut [111]. Taken together, Ahr likely enhances the immunosurveillance of the barrier organs through the c-kit. Additionally, c-kit and its receptor stem cell factor (SCF) are essential to induce proliferation and differentiation of mast cell precursors, reviewed in [113].

Langerhans cells (LCs) are specialized DCs of the epidermis that express higher levels of Ahr and Ahr repressor (Ahrr) [114]. Ablation of Ahr is associated with suppressed IDO and costimulatory molecules CD40, CD80, and CD24a, as well as less granular and smaller LCs [114]. Also, it is shown that Ahr deficiency impairs LCs maturation, which is related to low 
GM-CSF produced by $\gamma \delta$ T cells [111]. However, the molecular basis of these observations is lacking.

\section{Ahr in Inflammation}

A large number of inflammatory-related genes have different frequencies of XREs in their promoter regions (Table 1), suggesting modulatory effects of Ahr on the inflammatory responses. Furthermore, several studies have linked inflammation and infection to downregulation of P450 expression using various animal models. As the relation between the expression of P450 and inflammation has been reviewed [30, 115], the current paper addresses the proposed mechanistic details of the regulatory role of Ahr on certain inflammatory mediators.

It is now clear that Ahr regulates inflammatory signals via cross talks with other signaling pathways such as NF- $\kappa \mathrm{B}$ pathway. This pathway has long been known to control the expressions of IL-1 $\beta$, IL-6, IL-8, TNF- $\alpha$, and other inflammatory genes. The oxidative stress induced by Ahr ligands may activate the noncanonical NF- $\kappa \mathrm{B}$ and AP-1 pathways, resulting in an exacerbated inflammation [116]. Moreover, TCDD augments the production of several chemokines that are known targets of the noncanonical NF- $\kappa \mathrm{B}$ pathway such as IL-8, B lymphocyte chemoattractant (BLC), CCchemokine ligand (CCL) 1, and macrophages chemotactic protein (MCP)-1, which further trigger inflammation [33], and see [30]. Recent study has proposed that TCDD activates the NF- $\kappa \mathrm{B}$ pathway by intracellular free calcium in microglial cells resulting in an upregulation of TNF- $\alpha$ accompanied by elevation in COX-2 [63].

Alternatively, two recent studies have suggested that Ahr exacerbates inflammation by enhancing the function of the mast cells. One of them suggests that FICZ-exposed human and murine mast cells produce reactive oxygen species, IL6, and IL-17 in response to cAMP-dependent signals [117]. The other one suggests that Ahr is present in three models of rat mast cell lines and that Kyn enhances the production of IL-6 in RBL2H3 cells [118]. These observations may suggest involvement of mast cells in the modulatory role of Ahr in chronic inflammation and autoimmunity.

On the other hand, more studies have suggested an antiinflammatory function of Ahr. For example, Ahr-deficient mice show enhanced TNF- $\alpha$ production [93]. An upregulation of TNF- $\alpha$ may activate the noncanonical NF- $\kappa \mathrm{B}$ pathway by a functional interaction between Ahr and RelB [33]. Several in vivo and in vitro studies, including ours, have documented that Ahr activation reduces IL-12 $[59,90]$, IL-6 $[14,90]$, and TNF- $\alpha[14,59,90]$ in mice and humans [119]. These observations are likely attributed to the inhibitory effect of Ahr/STAT1 on the transcriptional activity of the NF$\kappa \mathrm{B}$ subunit $\mathrm{P} 50$ [90] and/or through suppression of histamine production [34]. More recently, we found that activation of Ahr by TCDD in vitro and in vivo induces cholinergic antiinflammatory system by upregulating acetylcholinesterasetargeting miR-132 [14]. This system is characterized by decreased proinflammatory molecules including IL-1 $\beta$, IL-6, IL-17, IFN- $\gamma$, and TNF- $\alpha$.
TABLE 1: Frequency of potential XREs boxes in the upstream sequences of selected inflammatory response-related genes.

\begin{tabular}{|c|c|c|c|}
\hline \multicolumn{2}{|c|}{ Innate immunity } & \multicolumn{2}{|c|}{ Adaptive immunity } \\
\hline Gene & $\begin{array}{c}\text { XREs } \\
\text { frequency }\end{array}$ & Gene & $\begin{array}{c}\text { XREs } \\
\text { frequency }\end{array}$ \\
\hline Il6 & 3 & $I l 2$ & 3 \\
\hline Il18 & 10 & Il4 & 2 \\
\hline \multirow[t]{2}{*}{$T N F \alpha$} & 1 & $I l 12 a$ & 3 \\
\hline & & Ill7 & 3 \\
\hline Illr1 & 5 & $I l 17 c$ & 6 \\
\hline Illr2 & 7 & Il21 & 4 \\
\hline Illrap & 12 & $I l 23 a$ & 5 \\
\hline \multirow[t]{2}{*}{ Illsrap } & 1 & & \\
\hline & & $I l 2 r b$ & 7 \\
\hline Tlr1 & 5 & $I l 2 r g$ & 5 \\
\hline Tlr2 & 2 & Il4ra & 9 \\
\hline Tlr3 & 3 & Il12rb1 & 4 \\
\hline Tlr4 & 5 & $I l 17 r$ & 6 \\
\hline $\operatorname{Tlr} 5$ & 9 & $I l 17 r b$ & 3 \\
\hline Tlr6 & 3 & Ill17rd & 7 \\
\hline $\operatorname{Tlr} 7$ & 4 & Ill7re & 6 \\
\hline $\operatorname{Tlr} 8$ & 2 & Ifngr & 11 \\
\hline $\operatorname{Tlr} 9$ & 3 & Ifngr2 & 5 \\
\hline Irakl & 5 & Jakl & 5 \\
\hline Irak4 & 4 & $J a k 2$ & 9 \\
\hline Traf6 & 5 & $J a k 3$ & 20 \\
\hline C3ar & 5 & Stat1 & 9 \\
\hline Il6st & 2 & Stat3 & 5 \\
\hline Kit & 11 & Stat5a & 9 \\
\hline Il18bp & 1 & Stat $5 b$ & 7 \\
\hline Lifat & 7 & $\operatorname{Irf1}$ & 6 \\
\hline
\end{tabular}

The genes are selected from [62].

An earlier report in Nature Medicine suggests mechanisms that may undertake the Ahr-mediated anti-inflammatory effects [120]. The authors suggest that lipoxins attenuate inflammation in infectious diseases in an Ahr/suppressor of cytokine signaling (SOCS)2-dependent manner. In later mechanistic study, they suggest that the lipoxin LXA4 and Kyn trigger an Ahr-dependent SOCS2 expression. In turn, SOCS2 targets TNF receptor associated factor (Traf)- 6 by ligation of Lys47 poly-ubiquitin chain and induction of proteasomal degradation, hindering proinflammatory cytokine expression by DCs [121]. Interestingly, both Socs 2 and Traf6 contain potential XREs boxes in the promoter regions [62], but the physiological significance remains unclear. Additionally, LXA4 and Kyn suppress several proinflammatory genes in a SOCS2-dependent manner, which, consequently, blocks many inflammatory pathways including TLR/MyD88, TLR/TRIF, IL-1r/MyD88, and CD40/CD154 [121]. 


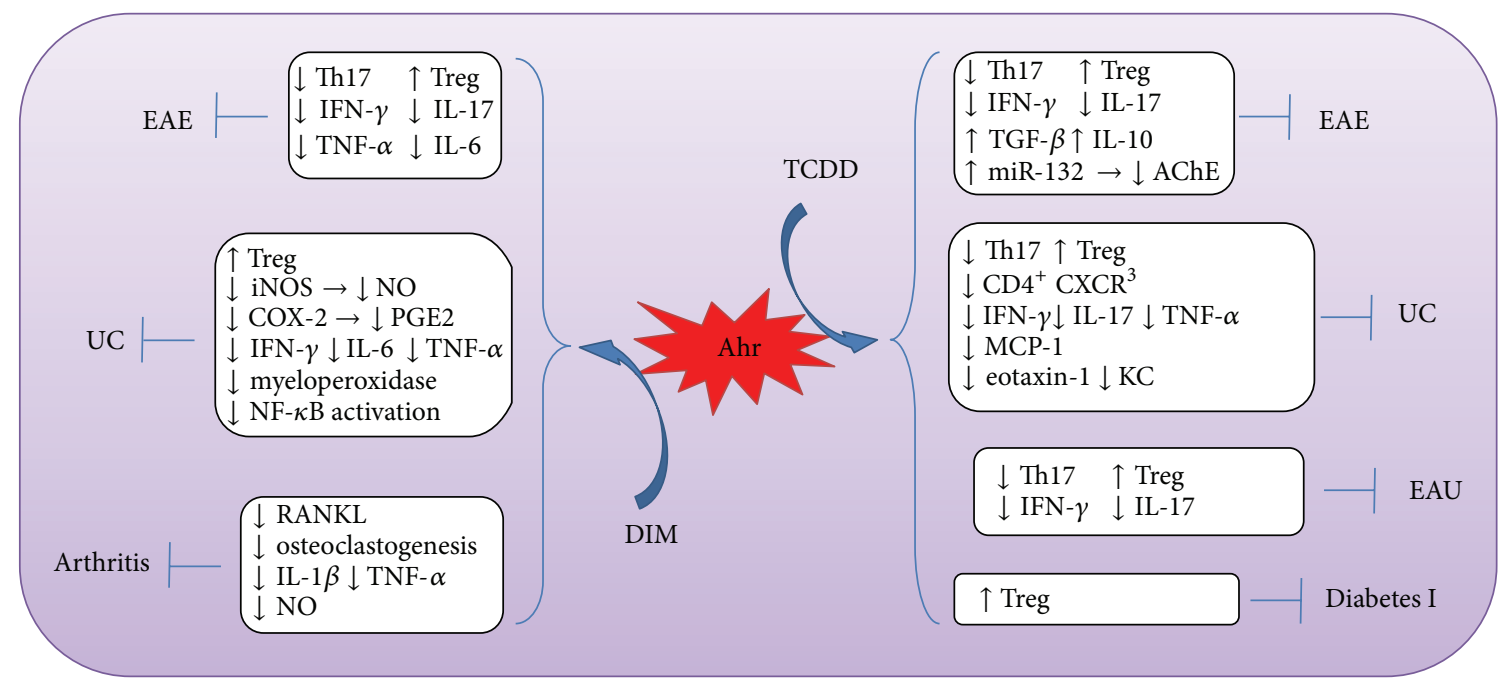

FIGURE 2: Ahr agonists suppress murine models of autoimmunity. Activation of Ahr by TCDD attenuates experimental autoimmune encephalomyelitis (EAE), ulcerative colitis (UC), experimental autoimmune uveoretinitis (EAU), and diabetes I by promoting differentiation of regulatory T cells (Tregs). With the exception of diabetes I, TCDD inhibits T helper (Th)-17, interferon (IFN)- $\gamma$, and interleukin (IL)17. In EAE, Ahr signaling results in upregulation of transforming growth factor (TGF)- $\beta$, IL-10, and acetylcholinesterase (AChE)-targeting microRNA (miR)-132. In addition to that mentioned above, TCDD downregulates tumor necrosis factor (TNF)- $\alpha$, monocyte chemotactic protein (MCP)-1, and keratinocyte chemoattractant (KC). Activation of Ahr by diindolylmethane (DIM) ameliorates EAE and UC by inducing Tregs and inhibiting proinflammatory cytokines including IFN- $\gamma$, IL- 6 , and tumor necrosis factor (TNF)- $\alpha$. Also, the DIM decreases inflammation in UC by inhibiting inducible nitric oxide synthase (iNOS) that produces nitric oxide (NO) and suppressing prostaglandin E2 (PGE2) by inhibiting COX-2, as well as inhibition of myeloperoxidase and nuclear factor (NF) $\kappa \mathrm{B}$ activation. DIM treatment inhibits the expression of receptor activator for ligand (RANKL), leading to the blockade of osteoclastogenesis and consequently an alleviation of experimental arthritis. In addition, the DIM reduces IL- $1 \beta$, TNF- $\alpha$, and NO in arthritis model.

\section{Ahr in Murine Models of Autoimmune Diseases}

The majority of autoimmune diseases may be prompted by prolonged inflammation, mainly in the individuals who have inherited sensitivity traits. Also, it is now clearly evident that many compounds alter the development of autoimmune conditions via Ahr. The animal models of autoimmune diseases have contributed substantially to achieve this understanding, which may lead to establishing effective treatment in humans.

A recently formed paradigm has demonstrated that activation of Ahr by TCDD enhances the $\mathrm{CD}^{+}{ }^{+} \mathrm{FoxP}^{+}$ cell differentiation. Therefore, TCDD treatment in vivo suppresses autoimmune inflammation in several murine models including EAE [13, 14], UC [15], experimental autoimmune uveoretinitis (EAU) [122], and type 1 diabetes [123] (Figure 2). In addition to promoting the differentiation of Tregs, TCDD ameliorates EAE, UC, and EAU by suppressing Th17, IL-17, and IFN- $\gamma$. Along with these observations, we have found that miR-132 mediates the effect of TCDD on the course of EAE by potentiating cholinergic anti-inflammatory system [14]. However, TCDD is a toxin with unfavorable pharmacological properties, which makes it invaluable therapeutically. Therefore, future research should focus on two approaches: firstly, to design or identify nontoxic Ahr ligands that resemble TCDD and, secondly, to give more emphasis on the identification of the molecular mechanisms that undertake the action of TCDD.
Several groups have demonstrated that natural Ahr ligands attenuate autoimmune inflammation. For example, the dietary indole derivatives indole-3-carbinol (I3C) and DIM promote the expansion of Tregs, while suppressing the induction of Th17 cells in EAE mice [55]. Comparable results are also obtained by DIM treatment in oxazolone-induced colitis [124]. The DIM also alleviates the inflammatory symptoms in a Treg-independent fashion. In DSS-induced colitis, the DIM reduces the disruption of the colonic architecture by suppressing colonic myeloperoxidase activity and the production of proinflammatory cytokines [125]. Furthermore, DIM attenuates experimental arthritis by the inhibition of the receptor activator for nuclear factor $\kappa \mathrm{B}$ ligand (RANKL), which leads to blockade of osteoclastogenesis [126].

The endogenous Ahr ligand, ITE, attenuates EAE symptoms by promoting Tregs expansion and inducing tolerogenic DCs that are capable of promoting the Tregs differentiation [89]. Similar results are observed when EAE mice are treated with nanoparticles carrying ITE and $M_{30 G_{35} 5}$ [127]. Conversely, treating mice with FICZ or indoxyl 3sulfate (I3S) worsens EAE, which is likely attributed to the prompted Th17 differentiation $[13,128]$. Interestingly, while systematic injection of FICZ does not affect EAE development, local application of FICZ enhances the development of Th17 cells and exacerbates autoimmune conditions [44]. In contrast, mice injected with the FICZ were protected from development of UC and showed decreased proinflammatory cytokines and an increased IL-22 production by Th17 cells 
[16]. Taken together, it is of importance to assess route of administration of Ahr ligand and to investigate the impact of an individual Ahr ligand in the different autoimmune disease models. Finally, we are confronted with pertinent questions that are toned to be answered. For example, which and under what conditions do the Ahr ligands play a role in attenuation of autoimmune disorders? How can that be applied pharmacologically?

As highlighted earlier in this review, Ahr is critically involved in the differentiation of Th17 and Tregs. Since these cells are reciprocally related, it may be suggested that Ahr is necessary to maintain the balance between these cells under normal conditions, and the augmentation or amelioration of autoimmunity by Ahr ligands is multifactorial including the rout of administration, model used, and the immunological conditions of the host.

\section{Concluding Remark}

It is clear that Ahr is not simply a transcription factor responding to toxins, but it is also critical in the physiological functions of immune cell compartments, in particular Th17, Tregs, and DCs that have prominent roles in inflammation and autoimmunity. A wide range of ligands ranging from small chemicals to dietary derived compounds can modulate the pathogenesis of autoimmune diseases through Ahr signaling. As it is discussed in this review, the epidemiological and mechanistic studies show much discrepancies about the Ahr-mediated regulation of inflammation and autoimmunity. Yet, studying Ahr signaling and alternative pathways is still a valuable approach for future clinical practice.

\section{Conflict of Interests}

The author declares that there is no conflict of interests regarding the publication of this paper.

\section{Acknowledgment}

This work was supported by the Deanship of Scientific Research, King Faisal University, Saudi Arabia, Grant 140154.

\section{References}

[1] E. A. Stevens, J. D. Mezrich, and C. A. Bradfield, "The aryl hydrocarbon receptor: a perspective on potential roles in the immune system," Immunology, vol. 127, no. 3, pp. 299-311, 2009.

[2] M. Veldhoen and J. H. Duarte, "The aryl hydrocarbon receptor: fine-tuning the immune-response," Current Opinion in Immunology, vol. 22, no. 6, pp. 747-752, 2010.

[3] C. Vogel, S. Donat, O. Döhr et al., "Effect of subchronic 2,3,7,8tetrachlorodibenzo-p-dioxin exposure on immune system and target gene responses in mice: calculation of benchmark doses for CYP1A1 and CYPIA2 related enzyme activities," Archives of Toxicology, vol. 71, no. 6, pp. 372-382, 1997.

[4] N. Tanimura, N. Kusunose, N. Matsunaga, S. Koyanagi, and S. Ohdo, "Aryl hydrocarbon receptor-mediated Cyplal expression is modulated in a CLOCK-dependent circadian manner," Toxicology, vol. 290, no. 2-3, pp. 203-207, 2011.
[5] H. Tsang, T.-Y. Cheung, S. P. Kodithuwakku et al., "2,3,7,8Tetrachlorodibenzo-p-dioxin (TCDD) suppresses spheroids attachment on endometrial epithelial cells through the downregulation of the Wnt-signaling pathway," Reproductive Toxicology, vol. 33, no. 1, pp. 60-66, 2012.

[6] K. W. Bock, "Ah receptor- and Nrf2-gene battery members: modulators of quinone-mediated oxidative and endoplasmic reticulum stress," Biochemical Pharmacology, vol. 83, no. 7, pp. 833-838, 2012.

[7] T. Nakahama, A. Kimura, N. Trung Nguyen et al., "Aryl hydrocarbon receptor deficiency in $\mathrm{T}$ cells suppresses the development of collagen-induced arthritis," Proceedings of the National Academy of Sciences of the United States of America, vol. 108, no. 34, pp. 14222-14227, 2011.

[8] D. Rohlman, D. Pham, Z. Yu, L. B. Steppan, and N. I. Kerkvliet, "Aryl hydrocarbon receptor-mediated perturbations in gene expression during early stages of $\mathrm{CD}^{+} \mathrm{T}$-cell differentiation," Frontiers in Immunology, vol. 3, article 223, 2012.

[9] H.-K. Wang, C.-H. Yeh, T. Iwamoto, H. Satsu, M. Shimizu, and M. Totsuka, "Dietary flavonoid naringenin induces regulatory $\mathrm{T}$ cells via an aryl hydrocarbon receptor mediated pathway," Journal of Agricultural and Food Chemistry, vol. 60, no. 9, pp. 2171-2178, 2012.

[10] B. W. Smith, S. S. Rozelle, A. Leung et al., "The aryl hydrocarbon receptor directs hematopoietic progenitor cell expansion and differentiation," Blood, vol. 122, no. 3, pp. 376-385, 2013.

[11] B. Stockinger, K. Hirota, J. Duarte, and M. Veldhoen, "External influences on the immune system via activation of the aryl hydrocarbon receptor," Seminars in Immunology, vol. 23, no. 2, pp. 99-105, 2011.

[12] N. T. Nguyen, H. Hanieh, T. Nakahama, and T. Kishimoto, "The roles of aryl hydrocarbon receptor in immune responses," International Immunology, vol. 25, no. 6, pp. 335-343, 2013.

[13] F. J. Quintana, A. S. Basso, A. H. Iglesias et al., "Control of Treg and TH17 cell differentiation by the aryl hydrocarbon receptor," Nature, vol. 453, no. 7191, pp. 65-71, 2008.

[14] H. Hanieh and A. Alzahrani, "MicroRNA-132 suppresses autoimmune encephalomyelitis by inducing cholinergic antiinflammation: a new Ahr-based exploration," European Journal of Immunology, vol. 43, no. 10, pp. 2771-2782, 2013.

[15] N. P. Singh, U. P. Singh, B. Singh, R. L. Price, M. Nagarkatti, and P. S. Nagarkatti, "Activation of Aryl hydrocarbon receptor (AhR) leads to reciprocal epigenetic regulation of Foxp3 and IL-17 expression and amelioration of experimental colitis," PLoS ONE, vol. 6, no. 8, Article ID e23522, 2011.

[16] I. Monteleone, T. Macdonald, F. Pallone, and G. Monteleone, "The aryl hydrocarbon receptor in inflammatory bowel disease: linking the environment to disease pathogenesis," Current Opinion in Gastroenterology, vol. 28, no. 4, pp. 310-313, 2012.

[17] H. Inoue, K. Mishima, S. Yamamoto-Yoshida et al., "Aryl hydrocarbon receptor-mediated induction of EBV reactivation as a risk factor for Sjögren's syndrome," Journal of Immunology, vol. 188, no. 9, pp. 4654-4662, 2012.

[18] L. Stejskalova, Z. Dvorak, and P. Pavek, "Endogenous and exogenous ligands of aryl hydrocarbon receptor: current state of art," Current Drug Metabolism, vol. 12, no. 2, pp. 198-212, 2011.

[19] R. Barouki, M. Aggerbeck, L. Aggerbeck, and X. Coumoul, "The aryl hydrocarbon receptor system," Drug Metabolism and Drug Interactions, vol. 27, no. 1, pp. 3-8, 2012.

[20] B. C. DiNatale, I. A. Murray, J. C. Schroeder et al., "Kynurenic acid is a potent endogenous aryl hydrocarbon receptor ligand 
that synergistically induces interleukin- 6 in the presence of inflammatory signaling," Toxicological Sciences, vol. 115, no. 1, pp. 89-97, 2010.

[21] E. C. Henry, S. L. Welle, and T. A. Gasiewicz, “TCDD and a putative endogenous AhR Ligand, ITE, elicit the same immediate changes in gene expression in mouse lung fibroblasts," Toxicological Sciences, vol. 114, no. 1, pp. 90-100, 2010.

[22] G. M. Lehmann, X. Xi, A. A. Kulkarni et al., "The aryl hydrocarbon receptor ligand ITE inhibits TGF $\beta 1$-induced human myofibroblast differentiation," The American Journal of Pathology, vol. 178, no. 4, pp. 1556-1567, 2011.

[23] E. A. Kiss, C. Vonarbourg, S. Kopfmann et al., "Natural aryl hydrocarbon receptor ligands control organogenesis of intestinal lymphoid follicles," Science, vol. 334, no. 6062, pp. 1561-1565, 2011.

[24] R. J. Wall, G. He, M. S. Denison et al., "Novel 2-aminoisoflavones exhibit aryl hydrocarbon receptor agonist or antagonist activity in a species/cell-specific context," Toxicology, vol. 297, no. 1-3, pp. 26-33, 2012.

[25] A. Poland, E. Glover, and A. S. Kende, "Stereospecific, high affinity binding of 2,3,7,8 tetrachlorodibenzo p dioxin by hepatic cytosol. Evidence that the binding species is receptor for induction of aryl hydrocarbon hydroxylase," The Journal of Biological Chemistry, vol. 251, no. 16, pp. 4936-4946, 1976.

[26] M. S. Denison, A. A. Soshilov, G. He, D. E. Degroot, and B. Zhao, "Exactly the same but different: promiscuity and diversity in the molecular mechanisms of action of the aryl hydrocarbon (dioxin) receptor," Toxicological Sciences, vol. 124, no. 1, pp. 1-22, 2011.

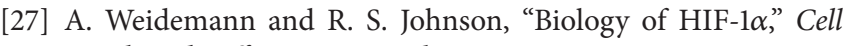
Death and Differentiation, vol. 15, no. 4, pp. 621-627, 2008.

[28] B. E. McIntosh, J. B. Hogenesch, and C. A. Bradfield, "Mammalian Per-Arnt-Sim proteins in environmental adaptation," Annual Review of Physiology, vol. 72, pp. 625-645, 2010.

[29] T. V. Beischlag, J. L. Morales, B. D. Hollingshead, and G. H. Perdew, "The aryl hydrocarbon receptor complex and the control of gene expression," Critical Reviews in Eukaryotic Gene Expression, vol. 18, no. 3, pp. 207-250, 2008.

[30] J. Vondráček, L. Umannová, and M. Machala, "Interactions of the aryl hydrocarbon receptor with inflammatory mediators: beyond CYP1A regulation," Current Drug Metabolism, vol. 12, no. 2, pp. 89-103, 2011.

[31] P. C. Boutros, I. D. Moffat, M. A. Franc et al., "Dioxin-responsive AHRE-II gene battery: identification by phylogenetic footprinting," Biochemical and Biophysical Research Communications, vol. 321, no. 3, pp. 707-715, 2004.

[32] A. Kimura, T. Naka, K. Nohara, Y. Fujii-Kuriyama, and T. Kishimoto, "Aryl hydrocarbon receptor regulates Statl activation and participates in the development of Th17 cells," Proceedings of the National Academy of Sciences of the United States of America, vol. 105, no. 28, pp. 9721-9726, 2008.

[33] C. F. A. Vogel and F. Matsumura, "A new cross-talk between the aryl hydrocarbon receptor and RelB, a member of the NF- $\kappa \mathrm{B}$ family," Biochemical Pharmacology, vol. 77, no. 4, pp. 734-745, 2009.

[34] K. Masuda, A. Kimura, H. Hanieh et al., "Aryl hydrocarbon receptor negatively regulates LPS-induced IL-6 production through suppression of histamine production in macrophages," International Immunology, vol. 23, no. 10, pp. 637-645, 2011.

[35] G. Xie, Z. Peng, and J.-P. Raufman, "Src-mediated aryl hydrocarbon and epidermal growth factor receptor cross talk stimulates colon cancer cell proliferation," American Journal of
Physiology-Gastrointestinal and Liver Physiology, vol. 302, no. 9, pp. G1006-G1015, 2012.

[36] G.-B. Jin, A. J. Moore, J. L. Head, J. J. Neumiller, and B. P. Lawrence, "Aryl hydrocarbon receptor activation reduces dendritic cell function during influenza virus infection," Toxicological Sciences, vol. 116, no. 2, pp. 514-522, 2010.

[37] T. Wang, K. L. Wyrick, M. R. Pecka, T. B. Wills, and B. A. Vorderstrasse, "Mechanistic exploration of AhR-mediated host protection against Streptococcus pneumoniae infection," International Immunopharmacology, vol. 13, no. 4, pp. 490-498, 2012.

[38] C. Esser, A. Rannug, and B. Stockinger, "The aryl hydrocarbon receptor in immunity," Trends in Immunology, vol. 30, no. 9, pp. 447-454, 2009.

[39] T. Negishi, Y. Kato, O. Ooneda et al., "Effects of aryl hydrocarbon receptor signaling on the modulation of Th1/Th2 balance," Journal of Immunology, vol. 175, no. 11, pp. 7348-7356, 2005.

[40] K. T. Jeong, S. J. Hwang, G. S. Oh, and J. H. Park, "FICZ, a Tryptophan photoproduct, suppresses pulmonary eosinophilia and Th2-type cytokine production in a mouse model of ovalbumininduced allergic asthma," International Immunopharmacology, vol. 13, no. 4, pp. 377-385, 2012.

[41] M. Tarkowski, B. Kur, M. Nocuń, and K. Sitarek, "Perinatal exposure of mice to TCDD decreases allergic sensitisation through inhibition of IL-4 production rather than T regulatory cell-mediated suppression," International Journal of Occupational Medicine and Environmental Health, vol. 23, no. 1, pp. 7583, 2010.

[42] B. P. Lawrence, M. S. Denison, H. Novak et al., "Activation of the aryl hydrocarbon receptor is essential for mediating the anti-inflammatory effects of a novel low-molecular-weight compound," Blood, vol. 112, no. 4, pp. 1158-1165, 2008.

[43] M. Rodríguez-Sosa, G. Elizondo, R. M. López-Durán, I. Rivera, F. J. Gonzalez, and L. Vega, "Over-production of IFN- $\gamma$ and IL12 in AhR-null mice," FEBS Letters, vol. 579, no. 28, pp. 64036410, 2005.

[44] M. Veldhoen, K. Hirota, A. M. Westendorf et al., “The aryl hydrocarbon receptor links TH17-cell-mediated autoimmunity to environmental toxins," Nature, vol. 453, no. 7191, pp. 106-109, 2008.

[45] M. Veldhoen, K. Hirota, J. Christensen, A. O'Garra, and B. Stockinger, "Natural agonists for aryl hydrocarbon receptor in culture medium are essential for optimal differentiation of Th17 T cells," Journal of Experimental Medicine, vol. 206, no. 1, pp. 43-49, 2009.

[46] F. J. Quintana, H. Jin, E. J. Burns et al., "Aiolos promotes $\mathrm{T}(\mathrm{H}) 17$ differentiation by directly silencing Il2 expression," Nature Immunology, vol. 13, no. 8, pp. 770-777, 2012.

[47] T. Nakahama, H. Hanieh, N. T. Nguyen et al., "Aryl hydrocarbon receptor-mediated induction of the microRNA-132/212 cluster promotes interleukin-17-producing T-helper cell differentiation," Proceedings of the National Academy of Sciences of the United States of America, vol. 110, no. 29, pp. 11964-11969, 2013.

[48] S. Trifari, C. D. Kaplan, E. H. Tran, N. K. Crellin, and H. Spits, "Identification of a human helper $\mathrm{T}$ cell population that has abundant production of interleukin 22 and is distinct from TH17, TH1 and TH2 cells," Nature Immunology, vol. 10, no. 8, pp. 864-871, 2009.

[49] J.-M. Ramirez, N. C. Brembilla, O. Sorg et al., "Activation of the aryl hydrocarbon receptor reveals distinct requirements for IL22 and IL-17 production by human T helper cells," European Journal of Immunology, vol. 40, no. 9, pp. 2450-2459, 2010. 
[50] W. Niedbala, J. C. Alves-Filho, S. Y. Fukada et al., "Regulation of type 17 helper T-cell function by nitric oxide during inflammation," Proceedings of the National Academy of Sciences of the United States of America, vol. 108, no. 22, pp. 9220-9225, 2011.

[51] G. Cui, X. Qin, L. Wu et al., "Liver X receptor (LXR) mediates negative regulation of mouse and human Th17 differentiation," The Journal of Clinical Investigation, vol. 121, no. 2, pp. 658-670, 2011.

[52] J. J. Heller, J. Qiu, and L. Zhou, "Nuclear receptors take center stage in Th17 cell-mediated autoimmunity," The Journal of Clinical Investigation, vol. 121, no. 2, pp. 519-521, 2011.

[53] J. D. Mezrich, J. H. Fechner, X. Zhang, B. P. Johnson, W. J. Burlingham, and C. A. Bradfield, "An interaction between kynurenine and the aryl hydrocarbon receptor can generate regulatory T cells," Journal of Immunology, vol. 185, no. 6, pp. 3190-3198, 2010.

[54] E. Hauben, S. Gregori, E. Draghici et al., "Activation of the aryl hydrocarbon receptor promotes allograft-specific tolerance through direct and dendritic cell-mediated effects on regulatory T cells," Blood, vol. 112, no. 4, pp. 1214-1222, 2008.

[55] M. Rouse, N. P. Singh, P. S. Nagarkatti, and M. Nagarkatti, "Indoles mitigate the development of experimental autoimmune encephalomyelitis by induction of reciprocal differentiation of regulatory T cells and Th17 cells," British Journal of Pharmacology, vol. 169, no. 6, pp. 1305-1321, 2013.

[56] L. Apetoh, F. J. Quintana, C. Pot et al., "The aryl hydrocarbon receptor interacts with c-Maf to promote the differentiation of type 1 regulatory T cells induced by IL-27," Nature Immunology, vol. 11, no. 9, pp. 854-861, 2010.

[57] R. Gandhi, D. Kumar, E. J. Burns et al., "Activation of the aryl hydrocarbon receptor induces human type 1 regulatory $\mathrm{T}$ celllike and Foxp $3^{+}$regulatory T cells," Nature Immunology, vol. 11, no. 9, pp. 846-853, 2010.

[58] J. L. Head and B. P. Lawrence, "The aryl hydrocarbon receptor is a modulator of anti-viral immunity," Biochemical Pharmacology, vol. 77, no. 4, pp. 642-653, 2009.

[59] G. Elizondo, M. Rodríguez-Sosa, E. Estrada-Muñiz, F. J. Gonzalez, and L. Vega, "Deletion of the aryl hydrocarbon receptor enhances the inflammatory response to leishmania major infection," International Journal of Biological Sciences, vol. 7, no. 9, pp. 1220-1229, 2011.

[60] S. Rutz, R. Noubade, C. Eidenschenk et al., "Transcription factor c-Maf mediates the TGF- $\beta$-dependent suppression of IL-22 production in TH17 cells," Nature Immunology, vol. 12, no. 12, pp. 1238-1245, 2011.

[61] C. Pot, "Aryl hydrocarbon receptor controls regulatory $\mathrm{CD} 4^{+} \mathrm{T}$ cell function," Swiss Medical Weekly, vol. 142, Article ID w13592, 2012.

[62] Y. V. Sun, D. R. Boverhof, L. D. Burgoon, M. R. Fielden, and T. R. Zacharewski, "Comparative analysis of dioxin response elements in human, mouse and rat genomic sequences," Nucleic Acids Research, vol. 32, no. 15, pp. 4512-4523, 2004.

[63] L. Zhao, Z. Jiang, Y. Jiang et al., "IL- $22^{+} \mathrm{CD} 4^{+} \mathrm{T}$-cells in patients with active systemic lupus erythematosus," Experimental Biology and Medicine, vol. 238, no. 2, pp. 193-199, 2013.

[64] W. Xu, R. Li, Y. Dai et al., "IL-22 secreting $\mathrm{CD}^{+}{ }^{+} \mathrm{T}$ cells in the patients with neuromyelitis optica and multiple sclerosis," Journal of Neuroimmunology, vol. 261, no. 1-2, pp. 87-91, 2013.

[65] L. F. da Rocha Jr., A. L. Duarte, A. T. Dantas et al., "Increased serum interleukin 22 in patients with rheumatoid arthritis and correlation with disease activity," The Journal of Rheumatology, vol. 39, no. 7, pp. 1320-1325, 2012.
[66] T. N. Lavoie, C. M. Stewart, K. M. Berg, Y. Li, and C. Q. Nguyen, "Expression of Interleukin-22 in Sjögren's Syndrome: significant correlation with disease parameters," Scandinavian Journal of Immunology, vol. 74, no. 4, pp. 377-382, 2011.

[67] N. Baba, M. Rubio, L. Kenins et al., "The aryl hydrocarbon receptor (AhR) ligand VAF347 selectively acts on monocytes and naive $\mathrm{CD} 4(+)$ Th cells to promote the development of IL22-secreting Th cells," Human Immunology, vol. 73, no. 8, pp. 795-800, 2012.

[68] N. I. Kerkvliet, D. M. Shepherd, and L. Baecher-Steppan, "T lymphocytes are direct, aryl hydrocarbon receptor (AhR)dependent targets of 2,3,7,8-tetrachlorodibenzo-p-dioxin (TCDD): AhR expression in both $\mathrm{CD}^{+}$and $\mathrm{CD}^{+} \mathrm{T}$ cells is necessary for full suppression of a cytotoxic $\mathrm{T}$ lymphocyte response by TCDD," Toxicology and Applied Pharmacology, vol. 185, no. 2, pp. 146-152, 2002.

[69] C. J. Funatake, N. B. Marshall, and N. I. Kerkvliet, "2,3,7,8Tetrachlorodibenzo-p-dioxin alters the differentiation of alloreactive $\mathrm{CD} 8^{+} \mathrm{T}$ cells toward a regulatory $\mathrm{T}$ cell phenotype by a mechanism that is dependent on aryl hydrocarbon receptor in $\mathrm{CD}^{+}{ }^{+}$T cells," Journal of Immunotoxicology, vol. 5, no. 1, pp. 8191, 2008.

[70] R. A. Williams, R. Greaves, M. Read, J. Timmis, P. S. Andrews, and V. Kumar, "In silico investigation into dendritic cell regulation of CD8Treg mediated killing of Th1 cells in murine experimental autoimmune encephalomyelitis," BMC Bioinformatics, vol. 14, no. S6, article S9, 2013.

[71] A. T. Endharti, Y. Okuno, Z. Shi et al., " $\mathrm{CD} 8^{+} \mathrm{CD} 122^{+}$regulatory $\mathrm{T}$ cells (Tregs) and $\mathrm{CD} 4^{+}$Tregs cooperatively prevent and cure $\mathrm{CD}^{+}$cell-induced colitis," Journal of Immunology, vol. 186, no. 1, pp. 41-52, 2011.

[72] J. W. Leavenworth, X. Tang, H. J. Kim, X. Wang, and H. Cantor, "Amelioration of arthritis through mobilization of peptide-specific $\mathrm{CD}^{+}$regulatory T cells," The Journal of Clinical Investigation, vol. 123, no. 3, pp. 1382-1389, 2013.

[73] T. S. Thurmond, J. E. Staples, A. E. Silverstone, and T. A. Gasiewicz, "The aryl hydrocarbon receptor has a role in the in vivo maturation of murine bone marrow B lymphocytes and their response to 2,3,7,8- tetrachlorodibenzo-p-dioxin," Toxicology and Applied Pharmacology, vol. 165, no. 3, pp. 227236, 2000.

[74] T. D. Bradshaw and D. R. Bell, "Relevance of the aryl hydrocarbon receptor (AhR) for clinical toxicology," Clinical Toxicology, vol. 47, no. 7, pp. 632-642, 2009.

[75] J. Qiu, J. J. Heller, X. Guo et al., "The aryl hydrocarbon receptor regulates gut immunity through modulation of innate lymphoid cells," Immunity, vol. 36, no. 1, pp. 92-104, 2012.

[76] Q. Zhang, D. E. Kline, S. Bhattacharya et al., "All-or-none suppression of B cell terminal differentiation by environmental contaminant 2, 3, 7, 8-tetrachlorodibenzo-p-dioxin," Toxicology and Applied Pharmacology, vol. 268, no. 1, pp. 17-26, 2013.

[77] C. E. W. Sulentic and N. E. Kaminski, “The long winding road toward understanding the molecular mechanisms for B-cell suppression by 2,3,7,8-tetrachlorodibenzo-p-dioxin," Toxicological Sciences, vol. 120, no. 1, pp. S171-S191, 2011.

[78] T. M. Fernando, S. D. Ochs, J. Liu, R. C. Chambers-Turner, and C. E. W. Sulentic, "2,3,7,8-Tetrachlorodibenzo-p-dioxin induces transcriptional activity of the human polymorphic hs1,2 enhancer of the $3^{\prime}$ Igh regulatory region," Journal of Immunology, vol. 188, no. 7, pp. 3294-3306, 2012.

[79] D. Frezza, V. Giambra, B. Tolusso et al., "Polymorphism of immunoglobulin enhancer element HS1,2A: allele * 2 associates 
with systemic sclerosis. Comparison with HLA-DR and DQ allele frequency," Annals of the Rheumatic Diseases, vol. 66, no. 9, pp. 1210-1215, 2007.

[80] R. Cianci, V. Giambra, C. Mattioli et al., "Increased frequency of Ig heavy-chain HS1,2-A enhancer *2 allele in dermatitis herpetiformis, plaque psoriasis, and psoriatic arthritis," Journal of Investigative Dermatology, vol. 128, no. 8, pp. 1920-1924, 2008.

[81] B. Tolusso, D. Frezza, C. Mattioli et al., "Allele * 2 of the HS1,2A enhancer of the Ig regulatory region associates with rheumatoid arthritis," Annals of the Rheumatic Diseases, vol. 68, no. 3, pp. 416-419, 2009.

[82] T. Yoshida, K. Katsuya, T. Oka et al., "Effects of AhR ligands on the production of immunoglobulins in purified mouse B cells," Biomedical Research, vol. 33, no. 2, pp. 67-74, 2012.

[83] N. I. Kerkvliet, "AHR-mediated immunomodulation: the role of altered gene transcription," Biochemical Pharmacology, vol. 77, no. 4, pp. 746-760, 2009.

[84] S. Teske, A. A. Bohn, J. P. Hogaboam, and B. P. Lawrence, "Aryl hydrocarbon receptor targets pathways extrinsic to bone marrow cells to enhance neutrophil recruitment during influenza virus infection," Toxicological Sciences, vol. 102, no. 1, pp. 89-99, 2008.

[85] J. L. Wheeler, K. C. Martin, and B. P. Lawrence, "Novel cellular targets of AhR underlie alterations in neutrophilic inflammation and inducible nitric oxide synthase expression during influenza virus infection," Journal of Immunology, vol. 190, no. 2, pp. 659-668, 2013.

[86] T. Veiga-Parga, A. Suryawanshi, and B. T. Rouse, "Controlling viral immuno-inflammatory lesions by modulating aryl hydrocarbon receptor signaling," PLoS Pathogens, vol. 7, no. 12, Article ID e1002427, 2011.

[87] I. Całkosiński, J. Rosińczuk-Tonderys, J. Bazan et al., "The influence of 2, 3, 7, 8-tetrachlorodibenzo-p-dioxin (TCDD) on hematological parameters during experimentally induced pleuritis in rats," Inflammation, vol. 36, no. 2, pp. 387-404, 2013.

[88] N. T. Nguyen, A. Kimura, T. Nakahama et al., "Aryl hydrocarbon receptor negatively regulates dendritic cell immunogenicity via a kynurenine-dependent mechanism," Proceedings of the National Academy of Sciences of the United States of America, vol. 107, no. 46, pp. 19961-19966, 2010.

[89] F. J. Quintana, G. Murugaiyan, M. F. Farez et al., "An endogenous aryl hydrocarbon receptor ligand acts on dendritic cells and $\mathrm{T}$ cells to suppress experimental autoimmune encephalomyelitis," Proceedings of the National Academy of Sciences of the United States of America, vol. 107, no. 48, pp. 20768-20773, 2010.

[90] T. Simones and D. M. Shepherd, "Consequences of AhR activation in steady-state dendritic cells," Toxicological Sciences, vol. 119, no. 2, pp. 293-307, 2011.

[91] A. Ilchmann, M. Krause, M. Heilmann, S. Burgdorf, S. Vieths, and M. Toda, "Impact of culture medium on maturation of bone marrow-derived murine dendritic cells via the aryl hydrocarbon receptor," Molecular Immunology, vol. 51, no. 1, pp. 42-50, 2012.

[92] J. Bankoti, A. Burnett, S. Navarro, A. K. Miller, B. Rase, and D. M. Shepherd, "Effects of TCDD on the fate of naive dendritic cells," Toxicological Sciences, vol. 115, no. 2, pp. 422-434, 2010.

[93] A. Kimura, T. Naka, T. Nakahama et al., "Aryl hydrocarbon receptor in combination with Stat1 regulates LPS-induced inflammatory responses," Journal of Experimental Medicine, vol. 206, no. 9, pp. 2027-2035, 2009.
[94] C. A. Beamer, B. P. Seaver, and D. M. Shepherd, "Aryl hydrocarbon receptor (AhR) regulates silica-induced inflammation but not fibrosis," Toxicological Sciences, vol. 126, no. 2, pp. 554-568, 2012.

[95] H. Sekine, J. Mimura, M. Oshima et al., "Hypersensitivity of aryl hydrocarbon receptor-deficient mice to lipopolysaccharideinduced septic shock," Molecular and Cellular Biology, vol. 29, no. 24, pp. 6391-6400, 2009.

[96] J. H. Shin, L. Zhang, O. Murillo-Sauca et al., "Modulation of natural killer cell antitumor activity by the aryl hydrocarbon receptor," Proceedings of the National Academy of Sciences of the United States of America, vol. 110, no. 30, pp. 12391-12396, 2013.

[97] C. J. Horras, C. L. Lamb, A. I. King, J. R. Hanley, and K. A. Mitchell, "Consequences of TCDD treatment on intra-hepatic lymphocytes during regeneration," Journal of Immunotoxicology, vol. 9, no. 4, pp. 359-367, 2012.

[98] A. M. Fullerton, R. A. Roth, and P. E. Ganey, "2, 3, 7, 8-TCDD enhances the sensitivity of mice to concanavalin A immunemediated liver injury," Toxicological and Applied Pharmacology, vol. 266, no. 2, pp. 317-327, 2013.

[99] G. Frumento, R. Rotondo, M. Tonetti, G. Damonte, U. Benatti, and G. B. Ferrara, "Tryptophan-derived catabolites are responsible for inhibition of $\mathrm{T}$ and natural killer cell proliferation induced by indoleamine 2,3-dioxygenase," Journal of Experimental Medicine, vol. 196, no. 4, pp. 459-468, 2002.

[100] T. Hughes, B. Becknell, A. G. Freud et al., "Interleukin-1 $\beta$ selectively expands and sustains interleukin $-22^{+}$immature human natural killer cells in secondary lymphoid tissue," Immunity, vol. 32, no. 6, pp. 803-814, 2010.

[101] C.-C. Lu and J.-K. Chen, "Resveratrol enhances perforin expression and NK cell cytotoxicity through NKG2D-dependent pathways," Journal of Cellular Physiology, vol. 223, no. 2, pp. 343351, 2010.

[102] E. Girardi, I. Maricic, J. Wang et al., "Type II natural killer T cells use features of both innate-like and conventional $\mathrm{T}$ cells to recognize sulfatide self antigens," Nature Immunology, vol. 13, no. 9, pp. 851-856, 2012.

[103] M. Kronenberg, "Toward an understanding of NKT cell biology: progress and paradoxes," Annual Review of Immunology, vol. 23, pp. 877-900, 2005.

[104] A. Bendelac, P. B. Savage, and L. Teyton, "The biology of NKT cells," Annual Review of Immunology, vol. 25, pp. 297-336, 2007.

[105] L. Moreira-Teixeira, M. Resende, M. Coffre et al., "Proinflammatory environment dictates the IL-17-producing capacity of human invariant NKT cells," Journal of Immunology, vol. 186, no. 10, pp. 5758-5765, 2011.

[106] J. Mjösberg, J. Bernink, C. Peters, and H. Spits, “Transcriptional control of innate lymphoid cells," European Journal of Immunology, vol. 42, no. 8, pp. 1916-1923, 2012.

[107] E. A. Kiss and A. Diefenbach, "Role of the aryl hydrocarbon receptor in controlling maintenance and functional programs of ROR $\gamma \mathrm{t}^{+}$innate lymphoid cells and intraepithelial lymphocytes," Frontiers in Immunology, vol. 3, article 124, 2012.

[108] S. Chappaz, C. Gärtner, H.-R. Rodewald, and D. Finke, "Kit ligand and Il7 differentially regulate peyer's patch and lymph node development," Journal of Immunology, vol. 185, no. 6, pp. 3514-3519, 2010.

[109] J. S. Lee, M. Cella, K. G. McDonald et al., "AHR drives the development of gut ILC22 cells and postnatal lymphoid tissues via pathways dependent on and independent of Notch," Nature Immunology, vol. 13, no. 2, pp. 144-152, 2012. 
[110] M. Girardi, J. M. Lewis, R. B. Filler, A. C. Hayday, and R. E. Tigelaar, "Environmentally responsive and reversible regulation of epidermal barrier function by $\gamma \delta$ T cells," Journal of Investigative Dermatology, vol. 126, no. 4, pp. 808-814, 2006.

[111] Y. Li, S. Innocentin, D. R. Withers et al., "Exogenous stimuli maintain intraepithelial lymphocytes via aryl hydrocarbon receptor activation," Cell, vol. 147, no. 3, pp. 629-640, 2011.

[112] S. Kadow, B. Jux, S. P. Zahner et al., "Aryl hydrocarbon receptor is critical for homeostasis of invariant $\gamma \delta$ T cells in the murine epidermis," Journal of Immunology, vol. 187, no. 6, pp. 3104-3110, 2011.

[113] D. S. El-Agamy, "Targeting c-kit in the therapy of mast cell disorders: current update," European Journal of Pharmacology, vol. 690, no. 1-3, pp. 1-3, 2012.

[114] B. Jux, S. Kadow, and C. Esser, "Langerhans cell maturation and contact hypersensitivity are impaired in aryl hydrocarbon receptor-null mice," Journal of Immunology, vol. 182, no. 11, pp. 6709-6717, 2009.

[115] A. E. Aitken, T. A. Richardson, and E. T. Morgan, "Regulation of drug-metabolizing enzymes and transporters in inflammation," Annual Review of Pharmacology and Toxicology, vol. 46, pp. 123149, 2006.

[116] K. Dreij, K. Rhrissorrakrai, K. C. Gunsalus, N. E. Geacintov, and D. A. Scicchitano, "Benzo[a]pyrene diol epoxide stimulates an inflammatory response in normal human lung fibroblasts through a p53 and JNK mediated pathway," Carcinogenesis, vol. 31, no. 6, pp. 1149-1157, 2010.

[117] R. Sibilano, B. Frossi, M. Calvaruso et al., "The aryl hydrocarbon receptor modulates acute and late mast cell responses," Journal of Immunology, vol. 189, no. 1, pp. 120-127, 2012.

[118] K. Maaetoft-Udsen, L. M. Shimoda, H. Frøkiær, and H. Turner, "Aryl hydrocarbon receptor ligand effects in RBL2H3 cells," Journal of Immunotoxicology, vol. 9, no. 3, pp. 327-337, 2012.

[119] C. Vlachos, B. M. Schulte, P. Magiatis, G. J. Adema, and G. Gaitanis, "Malassezia-derived indoles activate the aryl hydrocarbon receptor and inhibit Toll-like receptor-induced maturation in monocyte-derived dendritic cells," British Journal of Dermatology, vol. 167, no. 3, pp. 496-505, 2012.

[120] F. S. Machado, J. E. Johndrow, L. Esper et al., "Antiinflammatory actions of lipoxin A4 and aspirin-triggered lipoxin are SOCS-2 dependent," Nature Medicine, vol. 12, no. 3, pp. 330-334, 2006.

[121] C. McBerry, R. M. Gonzalez, N. Shryock, A. Dias, and J. Aliberti, "SOCS2-induced proteasome-dependent TRAF6 degradation: a common anti-inflammatory pathway for control of innate immune responses," PLoS ONE, vol. 7, no. 6, Article ID e38384, 2012.

[122] L. Zhang, J. Ma, M. Takeuchi et al., "Suppression of experimental autoimmune uveoretinitis by inducing differentiation of regulatory T cells via activation of aryl hydrocarbon receptor," Investigative Ophthalmology and Visual Science, vol. 51, no. 4, pp. 2109-2117, 2010.

[123] N. I. Kerkvliet, L. B. Steppan, W. Vorachek et al., "Activation of aryl hydrocarbon receptor by TCDD prevents diabetes in NOD mice and increases Foxp $3^{+}$T cells in pancreatic lymph nodes," Immunotherapy, vol. 1, no. 4, pp. 539-547, 2009.

[124] Z. Huang, Y. Jiang, Y. Yang et al., "3, 3'-diindolylmethane alleviates oxazolone-induced colitis through Th2/Th17 suppression and Treg induction," Molecular Immunology, vol. 53, no. 4, pp. 335-344, 2013.
[125] Y. H. Kim, H.-S. Kwon, D. H. Kim et al., “3,3'-diindolylmethane attenuates colonic inflammation and tumorigenesis in mice," Inflammatory Bowel Diseases, vol. 15, no. 8, pp. 1164-1173, 2009.

[126] L. Dong, S. Xia, F. Gao, D. Zhang, J. Chen, and J. Zhang, " 3,3 '-diindolylmethane attenuates experimental arthritis and osteoclastogenesis," Biochemical Pharmacology, vol. 79, no. 5, pp. 715-721, 2010.

[127] A. Yeste, M. Nadeau, E. J. Burns, H. L. Weiner, and F. J. Quintana, "Nanoparticle-mediated codelivery of myelin antigen and a tolerogenic small molecule suppresses experimental autoimmune encephalomyelitis," Proceedings of the National Academy of Sciences of the United States of America, vol. 109, no. 28, pp. 11270-11275, 2012.

[128] S. J. Hwang, Y. J. Hwang, M. O. Yun, J. H. Kim, G. S. Oh, and J. H. Park, "Indoxyl 3-sulfate stimulates Th17 differentiation enhancing phosphorylation of c-Src and STAT3 to worsen experimental autoimmune encephalomyelitis," Toxicology Letters, vol. 220, no. 2, pp. 109-117, 2013. 


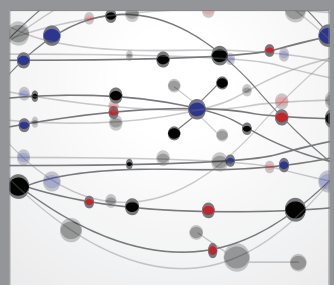

The Scientific World Journal
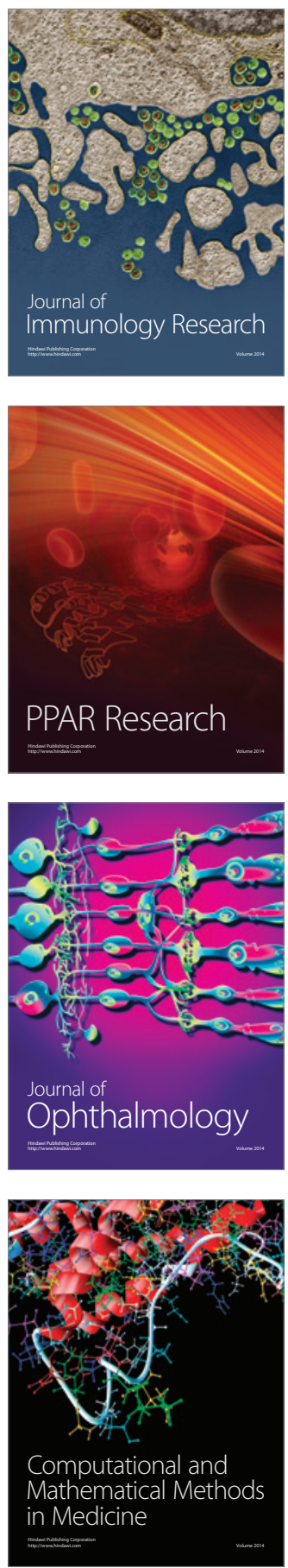

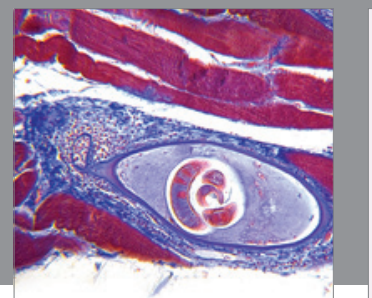

Gastroenterology

Research and Practice
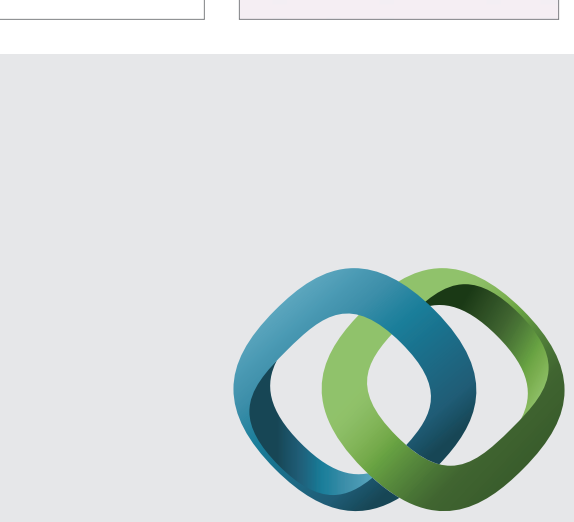

\section{Hindawi}

Submit your manuscripts at

http://www.hindawi.com
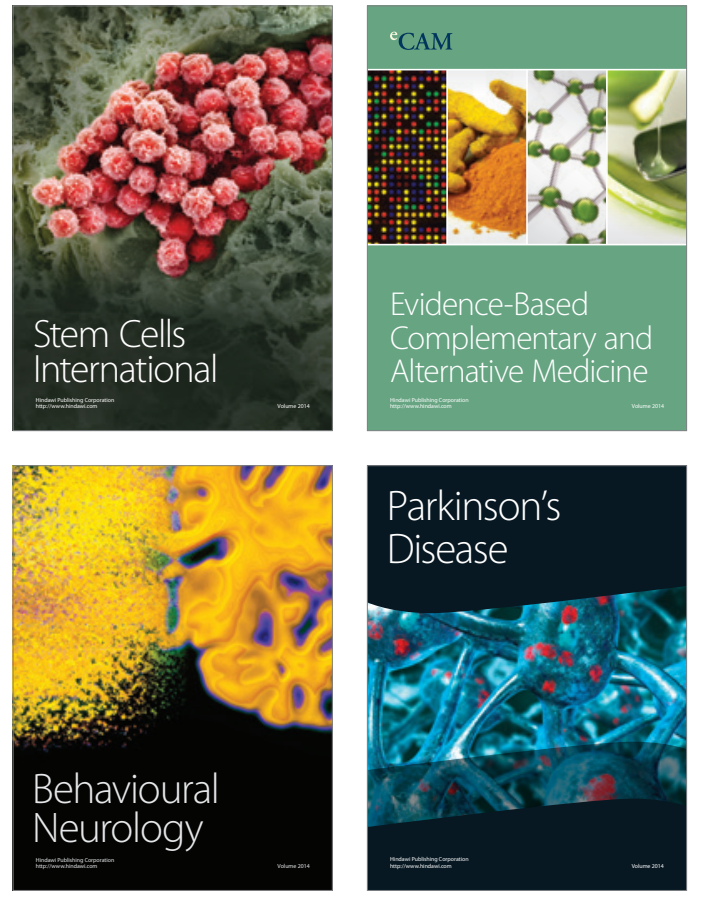
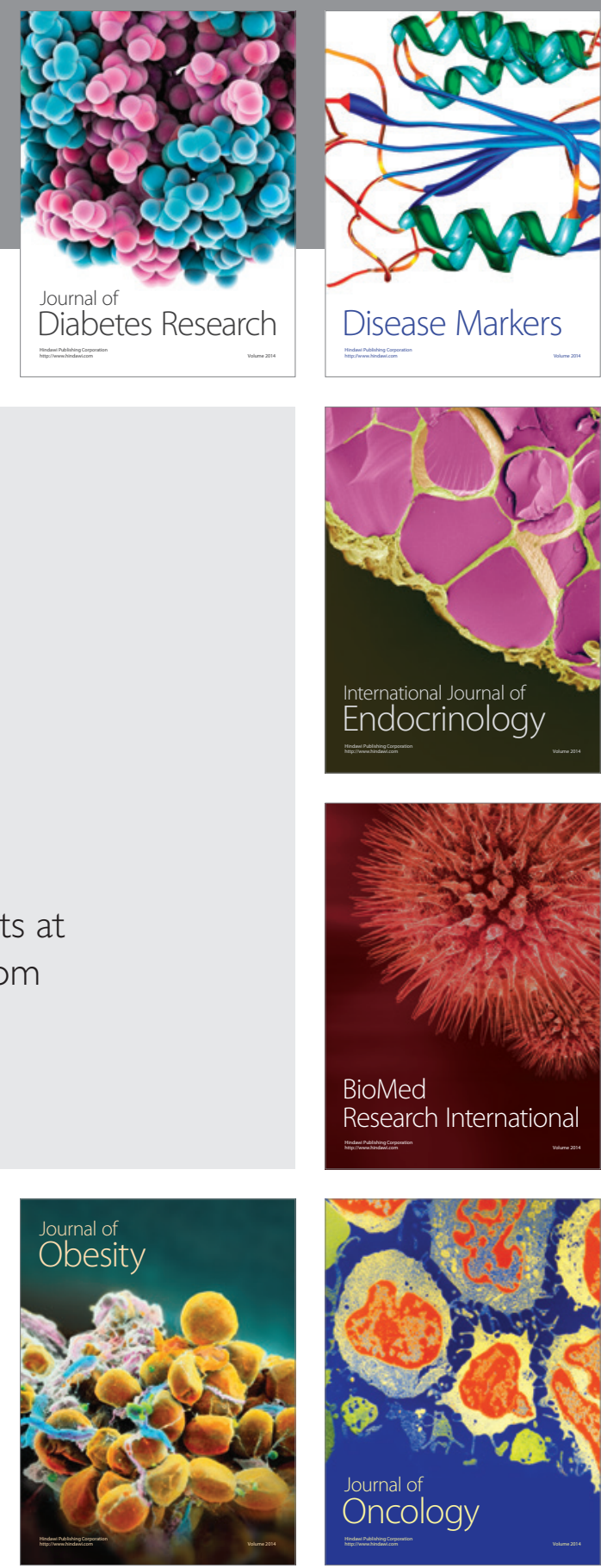

Disease Markers
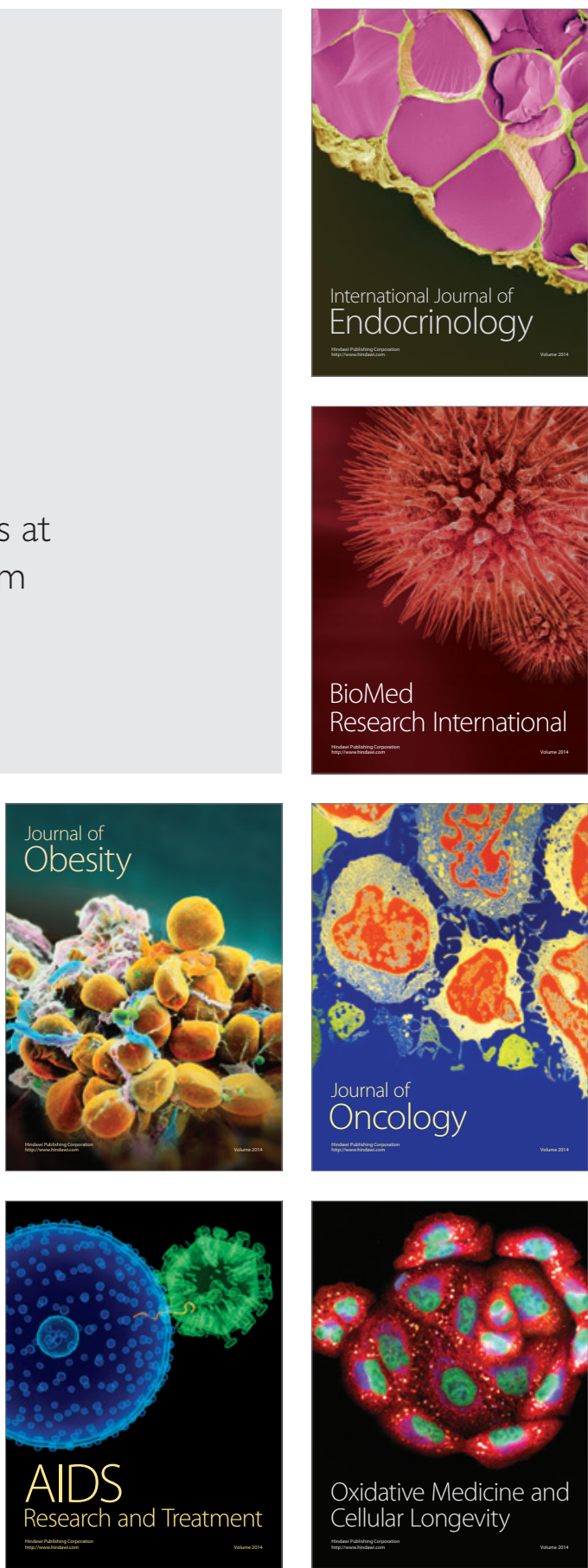